\title{
IAMJ
}

INTERNATIONAL

AYURVEDIC

MEDICAL JOURNAL

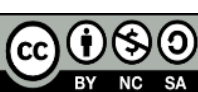

[d] 0

Review Article

ISSN: 23205091

Impact Factor: 5.344

\section{A BOOK REVIEW ON BHRIGU SAMHITA}

Krishnapriya A. $\mathbf{S}^{1}$, Praveen B. $\mathrm{S}^{2}$

${ }^{1}$ Post Graduate scholar, Post Graduate Dept of Pancakarma, Alva's Ayurveda Medical College, Moodbidri. Karnataka, India

${ }^{2}$ Professor \& Head, Post Graduate Dept of Pancakarma, Alva's Ayurveda Medical College, Moodbidri. Karnataka, India

Corresponding Author: as.krishnapriya27@gmail.com

https://doi.org/10.46607/iamj2908020280

(Published online: August 2020)

Open Access

(C) International Ayurvedic Medical Journal, India 2020

Article Received: 29/07/2020 - Peer Reviewed: 07/08/2020 - Accepted for Publication: 07/08/2020

Check for updates

Editor: Dr T M Rao

Year of publication:2010

ISBN: 9788122310214

Pages:310

Price: 295

Binding: Paperback

Published by: Pustak mahal, New Delhi

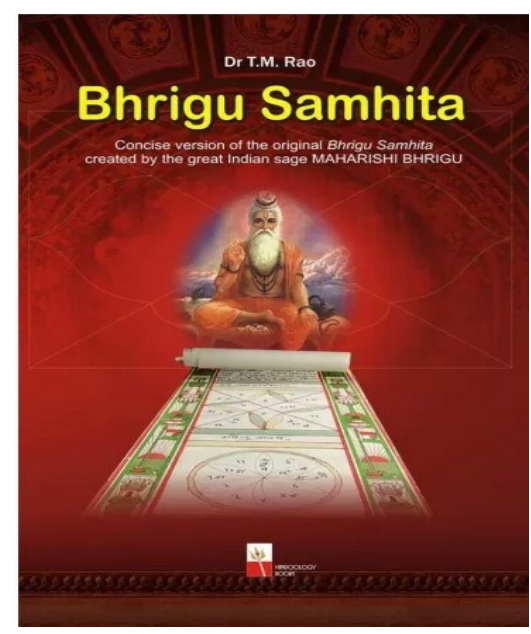




\section{INTRODUCTION}

Bhrigu Samhita is an astrological classic written by Maharshi Bhrigu in the Vedic period. This was the first treatise on predictive astrology. This book is a concise version of the original Bhrigu Samhita. This treatise contains 5 million horoscopes, in which he wrote down the fate of every being in the universe. He gave his predictions on different types of horoscopes compiled by him with the help of Lord Ganesha in a brief and concise manner. It is specifically written to understand the needs and interests of both laymen and experts. It imparts useful information on how to find out the character of a native, moral inclination, fortunes and misfortunes in various walks of life. Each content explained in the various chapters would enable to predict the future of the native and helps to form an opinion as to how a planet is disposed in a particular nativity.

About the author: Bhrigu is Manasaputra (wish-bornson) of Lord Brahma, who simply wished him into existence, to assist the processes of creation. Bhrigu is credited as the father of Hindu astrology, and the first astrological treatise Bhrigu Samhita is attributed to his authorship. Although the available evidence suggests that it was compiled over a period of time by the various students of Bhrigu. It is a confirmed fact that Saint Bhrigu was the first compiler of predictive astrology, which came to be known as the $5^{\text {th }} v e d a$ of treta yuga, which is an ancient age marking the beginning of the hindu culture. He compiled about 5 lakhs horoscopes with the help of Lord Ganesha and recorded details and events of the persons along with their ages. The study culminated in the birth of the shastra of determining the quality of hora, known as the Brihat Prasara Hora Shastra

About the translator

Dr T.M. Rao (Turaga Madhusudhana Rao) was born on July 3, 1927 at Guntur in Andhra Pradesh. He did his B.Sc (Hons) and M.Sc. (Research) from the Andhra University at Waltair. He had keen interest in Medical Astrology and started giving his opinions on health matters in 1997 to the different patients who were undergoing treatment in the various Corporate Hospitals. The Open International University for
Complementary Medicines, Colombo conferred upon him D.Sc in November 1997. He got several titles from different Astrological Associations and Bodies. He has authored two books Marriage Matching Astrologically and Astrology for Layman published by Pustak Mahal, New Delhi, which have received wide appreciation from all over India and abroad.

About the book in this book 12 chapters are describing with the ascendant based upon planetary positions with signs such as Aries, Taurus, Gemini, Cancer, Leo, Virgo, Libra, Scorpio, Sagittarius, Capricorn, Aquarius and Pisces. These horoscopes were based upon the planetary positions of the Sun, the Moon, Mercury, Venus, Mars, Jupiter, Saturn, Dragon's head (rahu) and Dragon's tail (ketu). Every ascendant has been treated with the placement of the planets in each of the 12 houses in a zodiacal diagram. First house deals with physique, will-power, fame, figure and physical complex. Second house with finance, family, speech, treasure and bondage. Third house with brothers and sisters, energy, physical work and courage. Fourth house with mother, motherly relations, land and buildings, peace and happiness. Fifth house with education, children, speech and knowledge. Sixth house with enemies, diseases, effort, magical powers, maternal grandfather, defeats and victories. Seventh house with wife, continued occupation, father-in-law and his family, sexual pleasures. Eighth house with wealth, age, daily routine, old and serious things helping in life, career and troubles. Ninth house with destiny, dharma, devotion, divine power and fame. Tenth house with father, government and society, occupation, luxury, authority. Eleventh house with wealth, income and gains, fulfillment of necessities. Twelfth house with expenditure, contact of foreign places. Each chapter containing daily predictions on monetary gains, monthly predictions on monetary gains, yearly predictions on monetary gains, predictions regarding age, stomach and other things helping the life course, predictions regarding physique, handsomeness, willpower and fame. First chapter deals with the significance of sign Aries and its predictions based on the planets. Second chapter deals with predictions of the 
planets with reference to Taurus sign. Third chapter deals with Gemini sign and its predictions. Fourth chapter deals with Cancer sign. Fifth chapter deals with Leo sign. Sixth chapter deals with Virgo sign. Seventh chapter deals with Libra sign. Eighth chapter deals with Scorpio sign. Ninth chapter deals with Sagittarius sign. Tenth chapter deals with Capricorn sign. Eleventh chapter deals with Aquarius sign and Twelfth chapter deals with Pisces sign.

Specialties of the Book: The primary view kept in this book is that the mystery of the whole human life is hidden in the nine planets of a horoscope, it will not be possible to discover the events of the whole life of the native till the effects of every planet is not clearly known without which the complicated science of astrology cannot be simplified. It is with that every ascendant is described in the book. The book gives valuable hints on how to find out the character of a native, his moral inclination, fortunes and misfortunes in various walks of life. This book will be used as an initial tool by the astrologers who will pursue this method also for making various kinds of predictions. It also provides useful information with regard to casting of horoscopes, points to be borne in mind while casting the Lagna, differences in the charts of men and women, the twelve signs, aspects of planets, friendship and opposition among planets, business of each planet, male and female signs, longevity and prosperity of the native. This is one of the astrological method used by the author for finding out the events based on the nine planets and their position in each house with reference to each sign as an ascendant, which highlights the events of a native in his lifetime.

\section{Source of Support: Nil \\ Conflict of Interest: None Declared}

How to cite this URL: Krishnapriya A. S \& Praveen B. S: A Book Review On Bhrigu Samhita. International Ayurvedic Medical Journal \{online\} 2020 \{cited August, 2020\} Available from: http://www.iamj.in/posts/images/upload/4216 4218.pdf 